\title{
Article \\ Overwintering and Yield Responses of Two Late-Summer Seeded Alfalfa Cultivars to Phosphate Supply
}

\author{
Yuntao Wang ${ }^{1,2}{ }^{\oplus}$, Jiageng Zhang ${ }^{3}$, Linqing Yu ${ }^{1,4, *}$, Zhanyou Xu ${ }^{5}\left(\mathbb{C}\right.$ and Deborah A. Samac ${ }^{5}(\mathbb{C}$ \\ 1 Grassland Research Institute of the Chinese Academy of Agricultural Sciences (GRI of CAAS), \\ Hohhot 010010, China; wytao88@163.com \\ 2 College of Tourism and Environment, Zhangiiakou University, Zhangjiakou 075000, China \\ 3 College of Grassland, Resources and Environment, Inner Mongolia Agricultural University, \\ Hohhot 010010, China; zjg15849124430@163.com \\ 4 School of Life Sciences, Inner Mongolia University, Hohhot 010021, China \\ 5 Plant Science Research Unit, Agricultural Research Service, USDA, 1991 Upper Buford Circle, \\ Saint Paul, MN 55108, USA; zhanyou.xu@usda.gov (Z.X.); debby.samac@usda.gov (D.A.S.) \\ * Correspondence: linqing_yu@126.com; Tel.: +86-186-8609-3509
}

Citation: Wang, Y.; Zhang, J.; Yu, L.; $\mathrm{Xu}, \mathrm{Z}$;; Samac, D.A. Overwintering and Yield Responses of Two Late-Summer Seeded Alfalfa Cultivars to Phosphate Supply. Agronomy 2022, 12, 327. https:// doi.org/10.3390/agronomy12020327

Academic Editors: Othmane Merah, Purushothaman

Chirakkuzhyil Abhilash, Magdi T. Abdelhamid, Hailin Zhang Bachar Zebib and Juan Jose Rios

Received: 23 December 2021

Accepted: 24 January 2022

Published: 26 January 2022

Publisher's Note: MDPI stays neutral with regard to jurisdictional claims in published maps and institutional affiliations.

Copyright: (C) 2022 by the authors. Licensee MDPI, Basel, Switzerland. This article is an open access article distributed under the terms and conditions of the Creative Commons Attribution (CC BY) license (https:// creativecommons.org/licenses/by/ $4.0 /)$.

\begin{abstract}
Phosphorus (P) is one of the essential nutrients for alfalfa (Medicago sativa L.) growth, but $\mathrm{P}$ deficiency in soil is a common phenomenon. Applying an appropriate amount of $\mathrm{P}$ fertilizer for alfalfa in the establishment year improves winter survival, helps achieve sustainable high yields, and promotes the best economic returns. The objective of this study was to determine the effect of different P fertilization rates $\left(0,22,44\right.$, and $\left.66 \mathrm{~kg} \mathrm{P} \mathrm{ha}^{-1}\right)$ on winter survival, forage yield, and root traits of two late-summer seeded alfalfa cultivars (dormant and semi-dormant) in the establishment and first production year. Our results showed that applying an appropriate amount of $\mathrm{P}$ fertilizer can increase forage yield and enhance the persistence of late-summer seeded alfalfa by promoting the development of crown and root traits and improving winter survival, especially for semi-dormant cultivars. Latesummer seeding and application of appropriate $\mathrm{P}$ fertilizer rates are effective agronomic methods for alfalfa in cold and arid winter regions, and can be used as strategies to improve fertility and stabilize soil from wind erosion for sustainable agriculture. To obtain high rate of survival in winter, the optimal $P$ fertilization rates for the dormant and semi-dormant alfalfa cultivars in this study were 31.4 and $41.3 \mathrm{~kg} \mathrm{P} \mathrm{ha}^{-1}$, whereas the optimum $\mathrm{P}$ application rates for high forage yields were 31.3 and $31.5 \mathrm{~kg} \mathrm{P} \mathrm{ha}^{-1}$, respectively.
\end{abstract}

Keywords: alfalfa; cold and arid winter region; P fertilization; forage productivity; root traits

\section{Introduction}

Alfalfa (Medicago sativa L.) is the most important perennial legume forage worldwide due to its high nutritional quality, high biomass production, and capacity to adapt to a wide range of environmental conditions [1]. It is a deep-rooted herbaceous perennial, capable of surviving extreme cold and drought, and can continue to produce for several years without needing to be replanted [2]. It can conserve soil and water and prevent soil erosion, improve soil fertility in forage-livestock systems through biological nitrogen fixation, boost the productivity of crop rotation as a whole, and reduce the need for chemical inputs [3]. Alfalfa stands at 3 to 5 years of age can provide sufficient $\mathrm{N}$ (from 130 to $200 \mathrm{~kg} \mathrm{~N} \mathrm{ha}^{-1}$ ) for 1 or 2 years of subsequent corn production, with significant energy savings and greenhouse gas reduction compared to $\mathrm{N}$ fertilizer production and use [4]. In the second year after establishment, alfalfa soil coverage can reach $95 \%$, with soil surface runoff and erosion decreased by $37 \%$ and $67 \%$, respectively, compared to annual crops [5]. Moreover, a 3-year-old alfalfa field had a 3.06\% higher soil moisture content and 2.42 times higher water infiltration rate than an open field [5]. Soil erosion decreased by $6210 \mathrm{tha}^{-1,}$ and the wind 
speed decreased by $2.4 \mathrm{~m} \mathrm{~s}^{-1}$ at $10 \mathrm{~cm}$ above the surface [6], and the stubble cover can prevent sandy soil from wind erosion in winter [7].

The growth and development of alfalfa in the establishment year is very important for winter survival and yield potential, especially root development. The root system is important for absorbing and transporting nutrients and water, and well-developed root systems are closely related to the yield and persistence of alfalfa [8]. The alfalfa crown, a transitional morphological structure located between the shoots and roots $[9,10]$, is very important for the development of new stems after each harvest and spring regrowth after winter dormancy [9]. Taproot development is strongly associated with seedling year total herbage yield [11]. The lateral roots are important for meeting the requirements of plants for nutrients and water during growth [12]. Root growth is influenced by the soil, climate, cultural treatments, and injury from insects and pathogens [13]. Root traits most influenced by the environment are the percentage of plants with determinate tap roots, taproot diameter, and the size of lateral roots. Traits least influenced by the environment are the position of determinate roots, number of lateral roots, position of lateral roots, and number of fibrous roots [11]. A developed root system is very important to the high yield and persistence of alfalfa [11]. Thus, agronomic practices are needed to improve alfalfa growth and development, and especially root growth and development.

To develop sustainable agricultural systems, China launched a series of programs to adjust planting management and animal husbandry with a rapid expansion of alfalfa acreage [14]. A program of "returning farmland to grassland" has been implemented in the vast agro-pastoral ecotone of China, including Inner Mongolia [15]. Because of the environmental features of Inner Mongolia, infertile soils, erosion, and long cold winters, sustainable agricultural systems are needed that are environmentally friendly and provide high economic efficiency [16]. Alfalfa has become the first choice for planting in this area because long-term planting of alfalfa not only improves the utilization of land and grassland, but also improves soil fertility, and protects the soil surface from the impact of rain and the scouring of wind [17]. Alfalfa is often planted in late spring or early summer in Inner Mongolia. The spring is characterized by low rainfall and wide fluctuations in air temperature. In summer, there are frequent precipitation, high temperatures, and fierce competition between alfalfa and weeds. Planting alfalfa during these periods is difficult, with high costs for plant management and maintenance. In late summer and early autumn, the temperature conditions are milder and precipitation is conducive to alfalfa germination and seedling growth [18] with reduced weed pressure. In addition, alfalfa can be planted after the harvest of early crops, which can increase economic benefits [19]. However, alfalfa sown in this period has a short growth period before the long and cold winter, which can impact overwintering and production. Fertilization is an important strategy to promote alfalfa growth. The soil nutrition of Inner Mongolia is characterized by insufficient phosphorus, moderate nitrogen, and excess potassium. Alfalfa has the capacity for symbiotic nitrogen fixation, with extra nitrogen supply shown to have little effect on alfalfa growth [20]. Soil-applied P fertilizer can increase the yield of alfalfa, and one large single $\mathrm{P}$ application lasted for at least five years [21]. A proper $\mathrm{P}$ application rate is essential for alfalfa plant survival and maximum stand development, productivity, and persistence [22], and will benefit the farmer economically by reducing fertilizer costs.

The objectives of this study were to: (i) determine if $P$ fertilization would improve the establishment and first-year yield of late-summer seeded alfalfa cultivars with different fall dormancy; and (ii) evaluate the relationships between winter survival, yields, and $\mathrm{P}$ application rate in a semi-arid continental climate zone of China.

\section{Materials and Methods}

\subsection{Experimental Site}

The experiment was carried out at the Agro-pastoral Experiment Station $\left(40^{\circ} 34^{\prime} \mathrm{N}\right.$; $111^{\circ} 45^{\prime}$ E; 1050 masl) at Shaerqin town, Tumote Banner, Inner Mongolia, China. The site has a semi-arid continental climate. Drought, cold, and wind-blown sand characterize the 
local environment. The mean annual air temperature is $5.6^{\circ} \mathrm{C}$, and the annual precipitation is about $400 \mathrm{~mm}$, primarily concentrated in June, July, and August. Soil samples taken to a $30 \mathrm{~cm}$ depth before planting were analyzed by a soil nutrient analyzer (Shandong Yuntang Intelligent Technology Co., Ltd., Weifang, China). The content of soil organic matter, total and available nitrogen $(\mathrm{N})$, available phosphorus $(\mathrm{P})$, and available potassium (K) content were quantified via oxidization with dichromate in the presence of sulfuric acid, and using the Kjeldahl method and alkaline hydrolysis diffusion, chlorostannousreduced molybdophosphoric blue, and a flame photometer by modifying the method of Griffiths [23]. The soil is a gray-cinnamon soil with $40.58 \%$ sand, $52.22 \%$ silt, $7.2 \%$ clay, $6 \%$ organic matter, total nitrogen of $1.09 \mathrm{~g} \mathrm{~kg}^{-1}$, available nitrogen of $69.45 \mathrm{mg} \mathrm{kg}^{-1}$, available phosphorus of $20.5 \mathrm{mg} \mathrm{kg}^{-1}$, available potassium of $93 \mathrm{mg} \mathrm{kg}^{-1}$, and $\mathrm{pH}=8.5$. The high $\mathrm{pH}$ is due to the quaternary fluvial alluvial lacustrine sediments of the parent material composed of gravel and various sandy materials, in addition to high levels of carbonates, which are brought to the surface by the evaporation of ground water. The precipitation and air temperature during the experiment are shown in Figure 1.

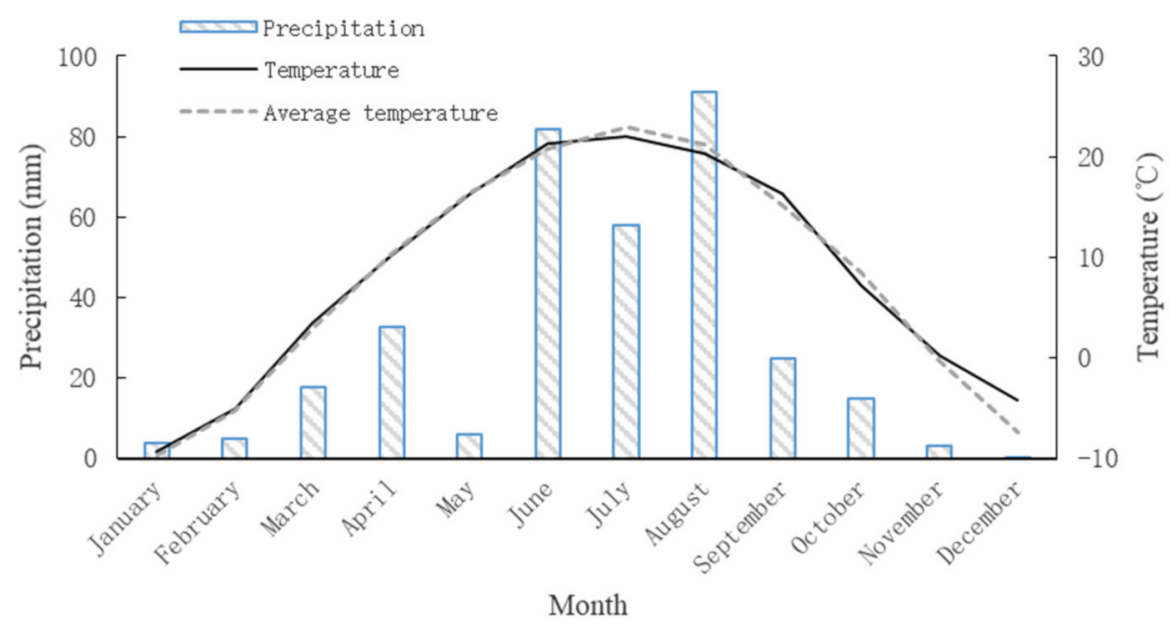

Figure 1. Precipitation and air temperatures in the Agro-pastoral Experiment Station in 2019 and 2020. The bars indicate the precipitation, the black line the temperature, and the gray dotted line shows the mean average temperature from 2011 to 2018.

\subsection{Plant Materials}

The cultivars used in this study were Zhongcao NO. 3 (ZC NO. 3) and Knight T, selected based on fall dormancy. The cultivar ZC NO. 3 is a fall dormant alfalfa, bred by Linqing $\mathrm{Yu}$ of the Grassland Research Institute of the Chinese Academy of Agricultural Sciences, Huhhot, China, and registered in 2009, with drought and cold resistance, good persistence, and suitability for cultivation in arid and cold areas. Knight $\mathrm{T}$ is a semi-dormant alfalfa, bought from Beijing Green Animal Husbandry Technology Development Co., Ltd., who imported it from Dairyland seed company, California, USA, and registered in China in 2012. It has high yield and cold tolerance, and is suited for planting in high-yielding irrigated areas. The germination rate of the two cultivars was more than $90 \%$.

\subsection{Field Design}

The experiment cultivars were planted on 9 August 2019, with a sowing rate of $15 \mathrm{~kg} \mathrm{ha}^{-1}$, row spacing of $30 \mathrm{~cm}$, seeds planting depth of 1-2 cm, and plot sizes of $3 \mathrm{~m} \times 5 \mathrm{~m}$. Treatments were arranged in a randomized complete block design with a split-plot arrangement with three replications. The whole treatment was P fertilization, the subplot treatments were cultivars. Whole treatments were surrounded by a $1 \mathrm{~m}$ wide strip of unfertilized ZC NO. 3 alfalfa to prevent border effects. The fertilization treatment was carried out on 10 September 2019 with $\left(\mathrm{NH}_{4}\right)_{2} \mathrm{HPO}_{4}$ (P content was $23.14 \%$ ) produced by Henan Jixin Chemical products Co., Ltd., Zhengzhou, China. The P fertilization rates were 
$0,22,44$, and $66 \mathrm{~kg} \mathrm{P} \mathrm{ha}^{-1}$, incorporated at a depth of $5-8 \mathrm{~cm}$ between rows within plots and then irrigated. There were no harvests in the establishment year. Plants were kept well-watered with supplementary sprinkler irrigation every 2 weeks for $6 \mathrm{~h}$, and weeds were removed by hand weeding on 25 August and 15 September. No diseases or pests were observed during the experimental period.

\subsection{Sampling and Plant Measurements}

In 2020, three cuts were performed (26 June, 19 August, and 26 September) with plants in each plot cut approximately $5 \mathrm{~cm}$ above the ground. After harvest, all border areas around plots were removed. The first cut was in the full bloom stage due to harvest delays caused by the COVID-19 pandemic; the second cut was at the early flowering stage; and the last cut was at 25 days before the first frost. Fresh weight was determined by weighing herbage from a $0.3 \mathrm{~m}^{2}$ section from the center of each plot. The samples were then dried at $65^{\circ} \mathrm{C}$ for $48 \mathrm{~h}$, re-weighed, and the dry matter yield per hectare was calculated. Measurements of yield components were: plant density at the first cut (number of plants within the $0.3 \mathrm{~m}^{2}$ section for the fresh weight sampling), and shoot mass (the average mass of 10 shoots from each plot), plant height, and the number of shoots per plant (the average of three plants from each plot) at each harvest [24]. Root phenotypes were assessed after the final cut by averaging three plants from each plot. Roots were excavated to a depth of $30 \mathrm{~cm}$ and then washed before being measured. Crown morphological characteristics measured were bud number, crown diameter, and crown depth, which was measured from the soil surface to the upper end of the crown. Root morphological characteristics measured were: taproot diameter at $1 \mathrm{~cm}$ below the crown, the number of lateral roots developing from the taproot, diameter of the first lateral root, and depth of the first lateral root from the crown. Winter survival was determined by counting the number of plants within $0.3 \mathrm{~m}^{2}$ in each plot on 5 October 2019, and then counting the number of live plants within the same area on 20 April 2020. The calculation of percent winter survival was:

$$
\text { Winter survival rate }=\frac{\text { Number of surviving plants in } 2020}{\text { Total number of plants in } 2019} \times 100 \%
$$

\subsection{Statistical Analyses}

All within-plot data were averaged for statistical analyses. These data were analyzed using Statistical Analysis Software (SAS software 9.4) and R studio (Version 1.3). Fall dormancy and $P$ treatment and their interactions were considered fixed effects and replication as random effects. The pairwise mean differences were compared by the least significant difference (LSD) with mean differences significant at $p \leq 0.05$. A generalized linear mixed model (GLM) was used for treatment comparisons, where treatment included the four $P$ treatments. A three-way repeated measures ANOVA was carried out using the functions of "anova_test () " and "get_anova_table( $)$ " from the R package rstatix [25].

\section{Results}

\subsection{Effect of $P$ Treatment on Yield Components}

The effects of different $P$ fertilizer rates on plant density were investigated on 26 June 2020. However, the alfalfa cultivars and $\mathrm{P}$ treatments did not have a significant impact on plant density (156 plants $\left.\mathrm{m}^{-2}, p>0.05\right)$.

The effects of different $P$ fertilizer rates on plant height were investigated at each harvest (Tables 1, 2 and S1). At the first cut, the plant height of ZC NO. 3 at each P fertilization rate was not significantly different to plant height at $0 \mathrm{~kg} \mathrm{P} \mathrm{ha}^{-1}$, whereas the plant height of Knight T increased with $44 \mathrm{~kg} \mathrm{P} \mathrm{ha}^{-1}$ compared to $0 \mathrm{~kg} \mathrm{P} \mathrm{ha}^{-1}$, an increase of $24.5 \%$. At the second cut, when applied at less than $66 \mathrm{~kg} \mathrm{P} \mathrm{ha}^{-1}$, the plant height of ZC NO. 3 was not significantly different from the control, but there was a significant difference at $66 \mathrm{~kg} \mathrm{P} \mathrm{ha}{ }^{-1}$. The plant height of Knight $\mathrm{T}$ increased first and then decreased with the increase in $\mathrm{P}$ fertilizer. When $\mathrm{P}$ was applied at $44 \mathrm{~kg} \mathrm{P} \mathrm{ha}^{-1}$, the plant height reached 
$65.89 \mathrm{~cm}, 40 \%$ higher than the control. At the third cut, application of $66 \mathrm{~kg} \mathrm{P} \mathrm{ha}^{-1}$ for both cultivars tested showed the highest height compared with $0 \mathrm{~kg} \mathrm{P} \mathrm{ha}^{-1}, 44.7 \%$ and $33.9 \%$ higher than that of the control, respectively. The plant heights of ZC NO. 3 at the first two cuts were larger than those of Knight $\mathrm{T}$ at each treatment. The average height of ZC NO. 3 was 67.50 and $61.32 \mathrm{~cm}, 14.5 \%$ and $17.1 \%$ higher than Knight T, respectively. However, the average plant height of Knight $\mathrm{T}$ at the third cut was $32.1 \%$ greater than that of ZC NO. 3. The cumulative plant height of ZC NO. 3 at each P fertilizer rate was not significantly different than that of $0 \mathrm{~kg} \mathrm{P} \mathrm{ha}^{-1}$. The cumulative plant height of Knight T increased first and then decreased with the increase in $\mathrm{P}$ fertilization. When applied at $44 \mathrm{~kg} \mathrm{P} \mathrm{ha}^{-1}$, the plant height was $30.1 \%$ higher than that of $0 \mathrm{~kg} \mathrm{P} \mathrm{ha}^{-1}$. However, there was no significant difference in cumulative plant height between the two cultivars.

Table 1. Analysis of variance $(p \leq 0.05)$ for the $\mathrm{P}$ application rate $(\mathrm{P})$, cultivar $(\mathrm{CV})$, and interactive effects on plant height, shoots per plant, and shoot mass in the Agro-pastoral Experiment Station at Shaerqin town, Tumote Banner, Inner Mongolia, China.

\begin{tabular}{cccccccccc}
\hline \multirow{2}{*}{ Treatments } & \multicolumn{3}{c}{ Plant Height } & \multicolumn{3}{c}{ Shoots per Plant } & \multicolumn{3}{c}{ Shoot Mass } \\
\cline { 2 - 10 } & $\mathbf{C V}$ & $\mathbf{P}$ & $\mathbf{C V} \times \mathbf{P}$ & $\mathbf{C V}$ & $\mathbf{P}$ & $\mathbf{C V} \times \mathbf{P}$ & $\mathbf{C V}$ & $\mathbf{P}$ & $\mathbf{C V} \times \mathbf{P}$ \\
\hline 1st cut & $<0.001$ & $<0.001$ & 0.118 & 0.683 & 0.089 & 0.567 & 0.786 & 0.005 & 0.268 \\
2nd cut & $<0.001$ & $<0.001$ & 0.065 & 0.049 & $<0.001$ & 0.768 & 0.135 & $<0.001$ & 0.001 \\
3rd cut & $<0.001$ & $<0.001$ & 0.519 & 0.653 & 0.002 & 0.341 & 0.007 & 0.002 & 0.550 \\
Annual & 0.068 & $<0.001$ & 0.112 & 0.345 & 0.001 & 0.121 & 0.080 & $<0.001$ & 0.057 \\
\hline
\end{tabular}

Table 2. Alfalfa plant height $(\mathrm{cm})$ in the Agro-pastoral Experiment Station at Shaerqin town, Tumote Banner, Inner Mongolia, China.

\begin{tabular}{|c|c|c|c|c|c|c|c|c|}
\hline \multirow{2}{*}{$\begin{array}{l}\text { Treatment } \\
\left(\mathrm{kg} \mathrm{P} \mathrm{ha}^{-1}\right)\end{array}$} & \multicolumn{2}{|c|}{ Cut 1} & \multicolumn{2}{|c|}{ Cut 2} & \multicolumn{2}{|c|}{ Cut 3} & \multicolumn{2}{|c|}{ Annual } \\
\hline & ZC NO. 3 & Knight T & ZC NO. 3 & Knight T & ZC NO. 3 & Knight T & ZC NO. 3 & Knight T \\
\hline 0 & $64.58 \mathrm{ABa}$ & $58.67 \mathrm{Ba}$ & $65.28 \mathrm{Aa}$ & $47.06 \mathrm{Bb}$ & $31.50 \mathrm{Bb}$ & $43.00 \mathrm{Ca}$ & $161.36 \mathrm{ABa}$ & $148.72 \mathrm{Ca}$ \\
\hline 22 & $75.67 \mathrm{Aa}$ & $58.58 \mathrm{Bb}$ & $74.78 \mathrm{Aa}$ & $64.50 \mathrm{Aa}$ & $33.31 \mathrm{Bb}$ & $48.69 \mathrm{Ba}$ & $183.75 \mathrm{Aa}$ & $171.78 \mathrm{Ba}$ \\
\hline 44 & $74.58 \mathrm{Aa}$ & $73.03 \mathrm{Aa}$ & $67.08 \mathrm{Aa}$ & $65.89 \mathrm{Aa}$ & $43.97 \mathrm{Ab}$ & $54.61 \mathrm{Aa}$ & $185.64 \mathrm{Aa}$ & 193.52 Aa \\
\hline 66 & $55.17 \mathrm{Ba}$ & $45.56 \mathrm{Ca}$ & $38.14 \mathrm{Ba}$ & $32.06 \mathrm{Ca}$ & $45.57 \mathrm{Ab}$ & $57.56 \mathrm{Aa}$ & $138.88 \mathrm{Ba}$ & 135.17 Da \\
\hline
\end{tabular}

Note: Different capital letters in the same column indicate significant differences among P treatments; different lowercase letters in the same row indicate significant differences between cultivars $(p<0.05) ; \mathrm{n}=3$.

The effects of different $\mathrm{P}$ fertilization rates on shoots per plant were investigated at each cut (Tables 1, 3 and S2). The shoots per plant of the two cultivars both increased first and then decreased with the increase in $P$ fertilization rates at the first and third cuts. At the first cut, ZC NO. 3 had more shoots per plant at $44 \mathrm{~kg} \mathrm{P} \mathrm{ha}^{-1}$ than the control, an increase of $97.0 \%$. However, Knight T had more shoots per plant at $22 \mathrm{~kg} \mathrm{P} \mathrm{ha}{ }^{-1}, 90.9 \%$ over the control. At the second cut, the shoots per plant of the two cultivars both increased with the increase in P fertilization rate. At $66 \mathrm{~kg} \mathrm{P} \mathrm{ha}^{-1}$, the shoots per plant of ZC NO. 3 and Knight T were 12.67 and 9.03, respectively, an increase of $94.9 \%$ and $55.4 \%$ from that of $0 \mathrm{~kg}$ $\mathrm{P} \mathrm{ha}^{-1}$, respectively. At the third cut, the ZC NO. 3 had more shoots per plant at $44 \mathrm{~kg} \mathrm{P}$ $\mathrm{ha}^{-1}$, an increase of $59.6 \%$ over the control. Knight $\mathrm{T}$ had more shoots per plant at $22 \mathrm{~kg}$ $\mathrm{P} \mathrm{ha}^{-1}$, an increase of $5.57 \%$ compared to the control. The annual number of shoots per plant increased first and then decreased with the increase in $\mathrm{P}$ fertilization rate. With the application of $\mathrm{P}$ fertilizer at $44 \mathrm{~kg} \mathrm{P} \mathrm{ha}^{-1}$, the annual shoots per plant of ZC NO. 3 reached 36.1 , which was $64.0 \%$ more than that at $0 \mathrm{~kg} \mathrm{P} \mathrm{ha}^{-1}$. There was no significant difference between the two cultivars at each $P$ fertilization rateof each cut. 
Table 3. Number of shoots per plant in the Agro-pastoral Experiment Station at Shaerqin town,

Tumote Banner, Inner Mongolia, China.

\begin{tabular}{|c|c|c|c|c|c|c|c|c|}
\hline \multirow{2}{*}{$\begin{array}{l}\text { Treatment } \\
\left.\text { (kg P ha-1) }^{-1}\right)\end{array}$} & \multicolumn{2}{|c|}{ Cut 1} & \multicolumn{2}{|c|}{ Cut 2} & \multicolumn{2}{|c|}{ Cut 3} & \multicolumn{2}{|c|}{ Annual } \\
\hline & ZC NO. 3 & Knight T & ZC NO. 3 & Knight T & ZC NO. 3 & Knight T & ZC NO. 3 & Knight T \\
\hline 0 & 7.67 Ba & $6.17 \mathrm{Ba}$ & $6.50 \mathrm{Ba}$ & $5.81 \mathrm{Aa}$ & 7.97 Aa & $12.92 \mathrm{Aa}$ & $22.14 \mathrm{Ca}$ & $24.89 \mathrm{ABa}$ \\
\hline 22 & $7.89 \mathrm{Ba}$ & $11.83 \mathrm{Aa}$ & $8.56 \mathrm{Ba}$ & $7.08 \mathrm{Aa}$ & $12.22 \mathrm{Aa}$ & $13.64 \mathrm{Aa}$ & $28.67 \mathrm{BCa}$ & $32.56 \mathrm{Aa}$ \\
\hline 44 & 15.11 Aa & $11.78 \mathrm{Aa}$ & $8.47 \mathrm{Ba}$ & $7.08 \mathrm{Aa}$ & $12.72 \mathrm{Aa}$ & $12.22 \mathrm{Aa}$ & $36.31 \mathrm{Aa}$ & $31.08 \mathrm{ABa}$ \\
\hline 66 & $10.36 \mathrm{ABa}$ & 8.67 Aba & $12.67 \mathrm{Aa}$ & $9.03 \mathrm{Aa}$ & $7.33 \mathrm{Aa}$ & $5.25 \mathrm{Aa}$ & $30.36 \mathrm{ABa}$ & $22.94 \mathrm{Ba}$ \\
\hline
\end{tabular}

Note: Different capital letters in the same column indicate significant differences among P treatments; different lowercase letters in the same row indicate significant differences between cultivars $(p<0.05)$; $\mathrm{n}=3$.

The effect of different $P$ fertilization rates on shoot mass were investigated at each cut (Tables 1, 4 and S3). At the first and second cut, the shoot mass of the two cultivars both increased first and then decreased with the increase in $\mathrm{P}$ fertilization. At the first cut, the shoot mass of two cultivars reached 7.11 and $5.05 \mathrm{~g}$ at $44 \mathrm{~kg} \mathrm{P}^{-1}$, increasing by $160.4 \%$ and $21.7 \%$ over that of $0 \mathrm{~kg} \mathrm{P} \mathrm{ha}^{-1}$. At the second cut, the shoot mass of ZC NO. 3 reached $6.80 \mathrm{~g}$ at $44 \mathrm{~kg} \mathrm{P} \mathrm{ha}^{-1}$, an increase of $31.8 \%$ over that of $0 \mathrm{~kg} \mathrm{P} \mathrm{ha}^{-1}$. The shoot mass of Knight T reached $8.31 \mathrm{~g}$ at $22 \mathrm{~kg} \mathrm{P} \mathrm{ha}^{-1}$, an increase of $69.9 \%$. At the third cut, the shoot mass of ZC NO. 3 increased with the increase in P fertilization; when P was applied at $66 \mathrm{~kg}$ $\mathrm{P} \mathrm{ha}^{-1}$, it reached $4.04 \mathrm{~g}, 79.6 \%$ greater than that of $0 \mathrm{~kg} \mathrm{P} \mathrm{ha}^{-1}$. There were no significant differences in the shoot mass of Knight $\mathrm{T}$ at the third cut. The annual shoot mass of the two cultivars increased first and then decreased with the increase in $\mathrm{P}$ fertilization rate. When $\mathrm{P}$ was applied at $44 \mathrm{~kg} \mathrm{P} \mathrm{ha}^{-1}$, the annual shoot mass of reached 16.71 and $16.23 \mathrm{~g}$, increasing by $64.8 \%$ and $36.4 \%$, respectively.

Table 4. Three cuttings of shoot mass (g) in the Agro-pastoral Experiment Station at Shaerqin town, Tumote Banner, Inner Mongolia, China.

\begin{tabular}{|c|c|c|c|c|c|c|c|c|}
\hline \multirow{2}{*}{$\begin{array}{l}\text { Treatment } \\
\left(\mathbf{k g} P \mathbf{h a}^{-1}\right)\end{array}$} & \multicolumn{2}{|c|}{ Cut 1} & \multicolumn{2}{|c|}{ Cut 2} & \multicolumn{2}{|c|}{ Cut 3} & \multicolumn{2}{|c|}{ Annual } \\
\hline & ZC NO. 3 & Knight T & ZC NO. 3 & Knight T & ZC NO. 3 & Knight T & ZC NO. 3 & Knight T \\
\hline 0 & $2.73 \mathrm{Bb}$ & $4.15 \mathrm{Ba}$ & $5.16 \mathrm{Aba}$ & $4.89 \mathrm{Ba}$ & $2.25 \mathrm{Ba}$ & $2.86 \mathrm{Aa}$ & 10.14 Ba & $11.90 \mathrm{Ba}$ \\
\hline 22 & $3.74 \mathrm{Ba}$ & $3.95 \mathrm{Ba}$ & $5.23 \mathrm{Abb}$ & $8.31 \mathrm{Aa}$ & $2.89 \mathrm{Abb}$ & $3.96 \mathrm{Aa}$ & $11.30 \mathrm{Bb}$ & $15.65 \mathrm{Aa}$ \\
\hline 44 & 7.11 Aa & $5.05 \mathrm{Ab}$ & $6.80 \mathrm{Aa}$ & $6.97 \mathrm{Aa}$ & $3.29 \mathrm{Aba}$ & $4.71 \mathrm{Aa}$ & $16.71 \mathrm{Aa}$ & 16.23 Aa \\
\hline 66 & $3.10 \mathrm{Ba}$ & $2.96 \mathrm{Ca}$ & $3.24 \mathrm{Ba}$ & $2.29 \mathrm{Cb}$ & $4.04 \mathrm{Aa}$ & $4.31 \mathrm{Aa}$ & 10.37 Ba & $9.56 \mathrm{Ba}$ \\
\hline
\end{tabular}

Note: Different capital letters in the same column indicate significant differences among P treatments; different lowercase letters in the same row indicate significant differences between cultivars $(p<0.05)$; $\mathrm{n}=3$.

\subsection{Effect of P Fertilizer Rate on Crown Traits}

The crown traits measured differed significantly among the P fertilizer treatments (Tables 5 and 6). The crown bud number of the two cultivars both increased with the increase in $\mathrm{P}$ fertilization rates. When applied at $66 \mathrm{~kg} \mathrm{P} \mathrm{ha}^{-1}$, the crown bud number reached 11.31 and 12.69 , an increase of $114.2 \%$ and $54.4 \%$ over that of $0 \mathrm{~kg} \mathrm{P} \mathrm{ha}^{-1}$, respectively. The crown depth of the two cultivars increased first and then decreased by P fertilizer treatments, and they were both deepest in the soil at $22 \mathrm{~kg} \mathrm{P} \mathrm{ha}^{-1}$, reaching 2.50 and 2.49 $\mathrm{cm}$, an increase of $4.60 \%$ and $33.2 \%$, respectively, over the control. The crown diameter of the two cultivars also increased first and then decreased with the increase in P fertilization rate. The crown diameter of ZC NO. 3 did not have a significant response to $\mathrm{P}$ fertilizer treatment. However, for Knight $\mathrm{T}$, the crown diameters at the application of $44 \mathrm{~kg} \mathrm{P}^{-1}$ reached $12.17 \mathrm{~mm}, 45.1 \%$ greater than those of the control. 
Table 5. Analysis of variance $(p \leq 0.05)$ for the $\mathrm{P}$ application rate $(\mathrm{P})$, cultivar $(\mathrm{CV})$, and interactive effects on the crown bud number, crown depth, crown diameter, taproot diameter, diameter of the first lateral root, depth of the first lateral root, and lateral root number in the Agro-pastoral Experiment Station at Shaerqin town, Tumote Banner, Inner Mongolia, China.

\begin{tabular}{|c|c|c|c|c|c|c|c|}
\hline Treatment & $\begin{array}{l}\text { Crown Bud } \\
\text { Number }\end{array}$ & Crown Depth & $\begin{array}{l}\text { Crown } \\
\text { Diameter }\end{array}$ & $\begin{array}{l}\text { Taproot } \\
\text { Diameter }\end{array}$ & $\begin{array}{l}\text { Diameter of First } \\
\text { Lateral Root }\end{array}$ & $\begin{array}{l}\text { Depth of First } \\
\text { Lateral Root }\end{array}$ & $\begin{array}{c}\text { Lateral Root } \\
\text { Number }\end{array}$ \\
\hline $\mathrm{CV}$ & 0.146 & 0.441 & 0.292 & 0.064 & $<0.001$ & 0.793 & $<0.001$ \\
\hline $\mathrm{P}$ & $<0.001$ & 0.002 & 0.175 & 0.002 & 0.013 & $<0.001$ & $<0.001$ \\
\hline $\mathrm{CV} \times \mathrm{P}$ & 0.340 & 0.017 & 0.208 & 0.155 & 0.007 & 0.144 & 0.003 \\
\hline
\end{tabular}

Table 6. Crown traits under different $P$ fertilization treatments in the Agro-pastoral Experiment Station at Shaerqin town, Tumote Banner, Inner Mongolia, China.

\begin{tabular}{ccccccc}
\hline \multirow{2}{*}{$\begin{array}{c}\text { Treatment } \\
\left(\mathbf{k g ~ h a}^{-1} \mathbf{)}\right.\end{array}$} & \multicolumn{2}{c}{ Crown Bud Number } & \multicolumn{2}{c}{ Crown Depth $(\mathbf{c m})$} & \multicolumn{2}{c}{ Crown Diameter (mm) } \\
\cline { 2 - 7 } & ZC NO. 3 & Knight T & ZC NO. 3 & Knight T & ZC NO. 3 & Knight T \\
\hline 0 & $5.28 \mathrm{Bb}$ & $8.22 \mathrm{Ba}$ & $2.39 \mathrm{ABa}$ & $1.87 \mathrm{Ba}$ & $10.00 \mathrm{Aa}$ & $8.39 \mathrm{Ba}$ \\
22 & $9.47 \mathrm{Aa}$ & $8.61 \mathrm{Ba}$ & $2.50 \mathrm{Aa}$ & $2.49 \mathrm{Aa}$ & $10.51 \mathrm{Aa}$ & $11.05 \mathrm{ABa}$ \\
44 & $10.72 \mathrm{Aa}$ & $11.61 \mathrm{ABa}$ & $1.84 \mathrm{BCa}$ & $1.99 \mathrm{ABa}$ & $10.38 \mathrm{Aa}$ & $12.17 \mathrm{Aa}$ \\
66 & $11.31 \mathrm{Aa}$ & $12.69 \mathrm{Aa}$ & $1.28 \mathrm{Cb}$ & $2.05 \mathrm{ABa}$ & $9.42 \mathrm{Aa}$ & $11.53 \mathrm{Aa}$ \\
\hline
\end{tabular}

Note: Different capital letters in the same column indicate significant differences among $\mathrm{P}$ treatments; different lowercase letters in the same row indicate significant differences between cultivars $(p<0.05) ; \mathrm{n}=3$.

\subsection{Effect of P Fertilizer Rate on Root Traits}

Root traits varied significantly due to cultivar and $P$ fertilizer treatments (Tables 5 and 7 ). The taproot diameter of the two cultivars first increased and then decreased with the increase in P fertilizer. However, the taproot diameter of ZC NO. 3 did not change significantly with increasing $\mathrm{P}$ fertilizer. The taproot diameter of Knight $\mathrm{T}$ reached 11.47 $\mathrm{mm}$ under $44 \mathrm{~kg} \mathrm{P} \mathrm{ha}^{-1}, 24.3 \%$ greater than that of $0 \mathrm{~kg} \mathrm{P} \mathrm{ha}^{-1}$. The first lateral root diameter of ZC NO. 3 significantly increased with $\mathrm{P}$ treatment up to $44 \mathrm{~kg} \mathrm{P} \mathrm{ha}^{-1}$, reaching $3.91 \mathrm{~mm}, 36.2 \%$ greater than that of $0 \mathrm{~kg} \mathrm{P} \mathrm{ha}{ }^{-1}$. The lateral root diameter of cultivar Knight $\mathrm{T}$ did not respond to $\mathrm{P}$ treatments. The depth of the first lateral root decreased first and then increased with the increased rate of $\mathrm{P}$ fertilizer in both cultivars, and reached 2.94 and $2.51 \mathrm{~cm}$ under $44 \mathrm{~kg} \mathrm{P} \mathrm{ha}^{-1}$, a decrease of $28.8 \%$ and $47.4 \%$ compared to that of $0 \mathrm{~kg} \mathrm{P} \mathrm{ha}{ }^{-1}$, respectively. The number of lateral roots decreased with increased P fertilization for Knight T. When $\mathrm{P}$ was applied at $66 \mathrm{~kg} \mathrm{P} \mathrm{ha}^{-1}$, the lateral root number reached 5.94 , a decrease of $56.7 \%$ compared to that of $0 \mathrm{~kg} \mathrm{P} \mathrm{ha}^{-1}$.

Table 7. Root traits under different $\mathrm{P}$ fertilization treatments in the Agro-pastoral Experiment Station at Shaerqin town, Tumote Banner, Inner Mongolia, China.

\begin{tabular}{|c|c|c|c|c|c|c|c|c|}
\hline \multirow{2}{*}{$\begin{array}{l}\text { Treatment } \\
\left(\mathrm{kg} \mathrm{P} \mathrm{ha}^{-1}\right)\end{array}$} & \multicolumn{2}{|c|}{ Taproot Diameter (mm) } & \multicolumn{2}{|c|}{ Diameter of the First Lateral Root (mm) } & \multicolumn{2}{|c|}{ Depth of First Lateral Root (cm) } & \multicolumn{2}{|c|}{ Number of Lateral Roots } \\
\hline & ZC NO. 3 & Knight T & ZC NO. 3 & Knight T & ZC NO. 3 & Knight T & ZC NO. 3 & Knight T \\
\hline 0 & 7.81 Aa & $9.23 \mathrm{Ba}$ & $2.87 \mathrm{ABa}$ & $2.02 \mathrm{Aa}$ & $4.13 \mathrm{Aa}$ & 4.77 Aa & $7.75 \mathrm{Ab}$ & $13.72 \mathrm{Aa}$ \\
\hline 22 & $8.70 \mathrm{Aa}$ & $9.24 \mathrm{Ba}$ & $3.67 \mathrm{Aa}$ & $2.02 \mathrm{Ab}$ & $3.94 \mathrm{ABa}$ & 4.07 ABa & $7.14 \mathrm{Ab}$ & $11.33 \mathrm{Aa}$ \\
\hline 44 & $9.18 \mathrm{Ab}$ & $11.47 \mathrm{Aa}$ & $3.91 \mathrm{Aa}$ & $2.15 \mathrm{Ab}$ & $2.94 \mathrm{Ca}$ & $2.51 \mathrm{Ca}$ & $5.83 \mathrm{Aa}$ & $7.92 \mathrm{Ba}$ \\
\hline 66 & $7.66 \mathrm{Aa}$ & $7.00 \mathrm{Ca}$ & $1.96 \mathrm{Ba}$ & $2.19 \mathrm{Aa}$ & $3.51 \mathrm{Ba}$ & $3.33 \mathrm{BCa}$ & $6.25 \mathrm{Aa}$ & $5.94 \mathrm{Ba}$ \\
\hline
\end{tabular}

Note: Different capital letters in the same column indicate significant differences among $\mathrm{P}$ treatments; different lowercase letters in the same row indicate significant differences between cultivars $(p<0.05) ; \mathrm{n}=3$.

The root traits of the two alfalfa cultivars had significant differences. When $\mathrm{P}$ fertilizer was less than $44 \mathrm{~kg} \mathrm{P} \mathrm{ha}^{-1}$, the taproot diameter of Knight $\mathrm{T}$ was greater than that of ZC NO. 3, the lateral root diameter of ZC NO. 3 was greater than that of Knight T, and Knight T had more lateral roots than ZC NO. 3.

\subsection{Effect of P Fertilizer Rate on Winter Survival}

The effects of $P$ fertilizer rate on winter survival were investigated on 20 April 2020 (Table 8 and Figure 2). The cultivars studied had a much greater effect on winter survival than 
P fertilizer rate. The winter survival rate of ZC NO. 3 was $91.4 \%$, and that of Knight T was $79.0 \%$. P fertilizer treatment had a significant effect on winter survival, with $44 \mathrm{~kg} \mathrm{P} \mathrm{ha}^{-1}$, the winter survival rate resulted in $87.6 \%$ and significantly greater than that at $0 \mathrm{~kg} \mathrm{P} \mathrm{ha}^{-1}$.

Table 8. Analysis of variance $(p \leq 0.05)$ for the $P$ application rate $(\mathrm{P})$ and cultivar $(\mathrm{CV})$ on the winter survival rate and forage yield in the Agro-pastoral Experiment Station at Shaerqin town, Tumote Banner, Inner Mongolia, China.

\begin{tabular}{cccccc}
\hline \multirow{2}{*}{ Treatment } & \multirow{2}{*}{ Winter Survival Rate } & \multicolumn{4}{c}{ Forage Yield } \\
\cline { 3 - 5 } & & 1st Cut & 2nd Cut & 3rd Cut & Annual \\
\hline $\mathrm{CV}$ & $<0.001$ & $<0.001$ & 0.459 & $<0.001$ & 0.123 \\
$\mathrm{P}$ & 0.094 & $<0.001$ & $<0.001$ & 0.186 & $<0.001$ \\
\hline
\end{tabular}

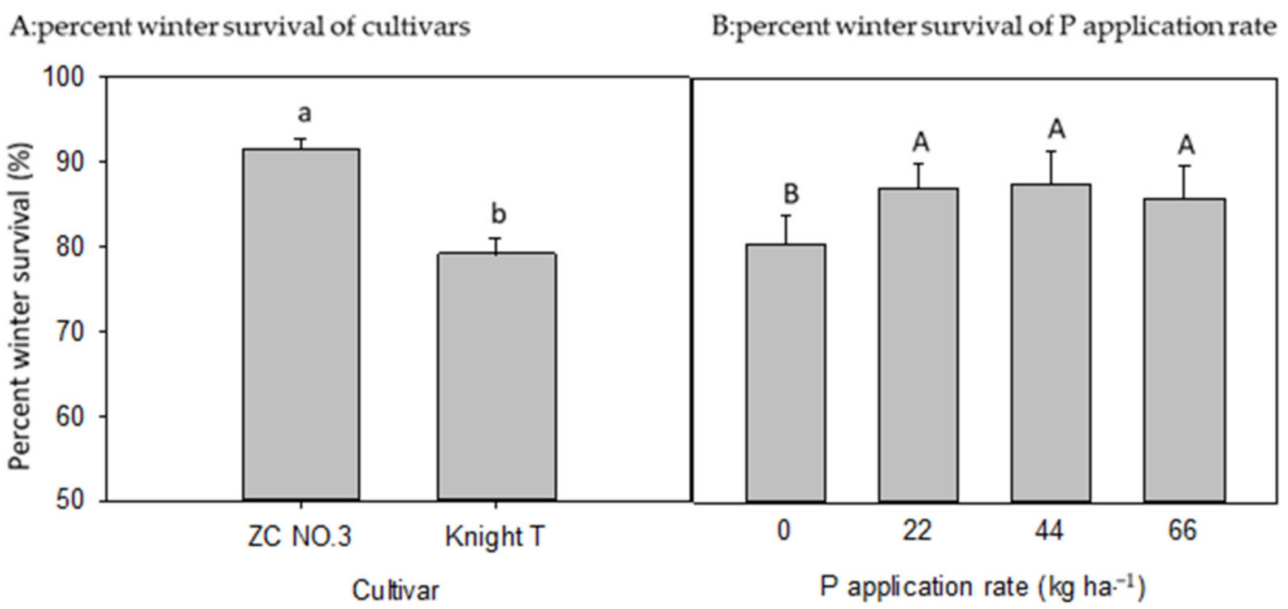

Figure 2. Winter survival by cultivar and $\mathrm{P}$ treatment in the Agro-pastoral Experiment Station at Shaerqin town, Tumote Banner, Inner Mongolia, China. (A) percent winter survival of the dormant cultivar ZC NO. 3 and semi-dormant cultivar Knight T. (B) percent winter survival by P application rate. Different capital letters above bars indicate significant differences between P treatments; different lowercase letters above bars indicate significant differences between cultivars; $n=3$.

However, the response curve and degree of response were different for the two cultivars (Figure 3). The winter survival rate of ZC NO. 3 would reach $94.2 \%$ at a $\mathrm{P}$ fertilization rate of $39.4 \mathrm{~kg} \mathrm{P}^{-1}$ according to the quadratic regression equation $\mathrm{Y}=86.465+0.394 \times \mathrm{P}-0.005 \times \mathrm{P}^{2}$. The winter survival rate of Knight $\mathrm{T}$ would reach $81.6 \%$ at a $\mathrm{P}$ fertilization rate of $41.3 \mathrm{~kg} \mathrm{P} \mathrm{ha}^{-1}$ according to the quadratic regression equation $\mathrm{Y}=74.775+0.330 \times \mathrm{P}-0.004 \times \mathrm{P}^{2}$. The average winter survival rate would reach $88.0 \%$ at a $\mathrm{P}$ application rate of $45.25 \mathrm{~kg} \mathrm{P} \mathrm{ha}^{-1}$ according to the quadratic regression equation $\mathrm{Y}=80.62+0.362 \times \mathrm{P}-0.004 \times \mathrm{P}^{2}$.

\subsection{Effect of P fertilizer Rate on Annual Forage Yield}

The forage yields of dormant and semi-dormant cultivars both showed a similar response to $\mathrm{P}$ fertilizer rate (Tables 8,9 and S4). At the first cut, the forage yield of the two cultivars increased first and then decreased with the increase in P fertilizer. At $44 \mathrm{~kg} \mathrm{P} \mathrm{ha}^{-1}$, the forage yield of ZC NO. 3 and Knight T reached 5534.32 and $5317.14 \mathrm{~kg} \mathrm{ha}^{-1}$, an increase of $62.6 \%$ and $143.6 \%$ over that of the control, respectively. At the second cut, the highest yield of ZC NO. 3 of $4117.65 \mathrm{~kg} \mathrm{ha}^{-1}$ was obtained under $44 \mathrm{~kg} \mathrm{P} \mathrm{ha}^{-1}$, an increase of $68.0 \%$ over that of the control. The highest yield of Knight $\mathrm{T}$ in cut 2, of $4379.08 \mathrm{~kg} \mathrm{ha}^{-1}$, was under $22 \mathrm{~kg} \mathrm{P} \mathrm{ha}^{-1}$, an increase of $83.6 \%$ over that of the control. At the third cut, the highest yield of ZC NO. 3, of $3377.05 \mathrm{~kg} \mathrm{ha}^{-1}$, was obtained under $44 \mathrm{~kg} \mathrm{P} \mathrm{ha}^{-1}$, an increase of $20.5 \%$ over that of the control, and that of Knight T, of $4065.57 \mathrm{~kg} \mathrm{ha}^{-1}$, was under $22 \mathrm{~kg} \mathrm{P} \mathrm{ha}^{-1}$, an increase of $37.8 \%$ over that of the control. Both cultivars had the 
highest annual forage yields when the $\mathrm{P}$ fertilizer was $44 \mathrm{~kg} \mathrm{P} \mathrm{ha}^{-1}$, reaching 13,029.02 and $13,017.78 \mathrm{~kg} \mathrm{ha}^{-1}$, an increase of $50.5 \%$ and $74.3 \%$ over those of the control, respectively. In the first cut, the yields of ZC NO. 3 were greater than those of Knight T, whereas in the third cut, the yields of ZC NO. 3 were less than those of Knight T.
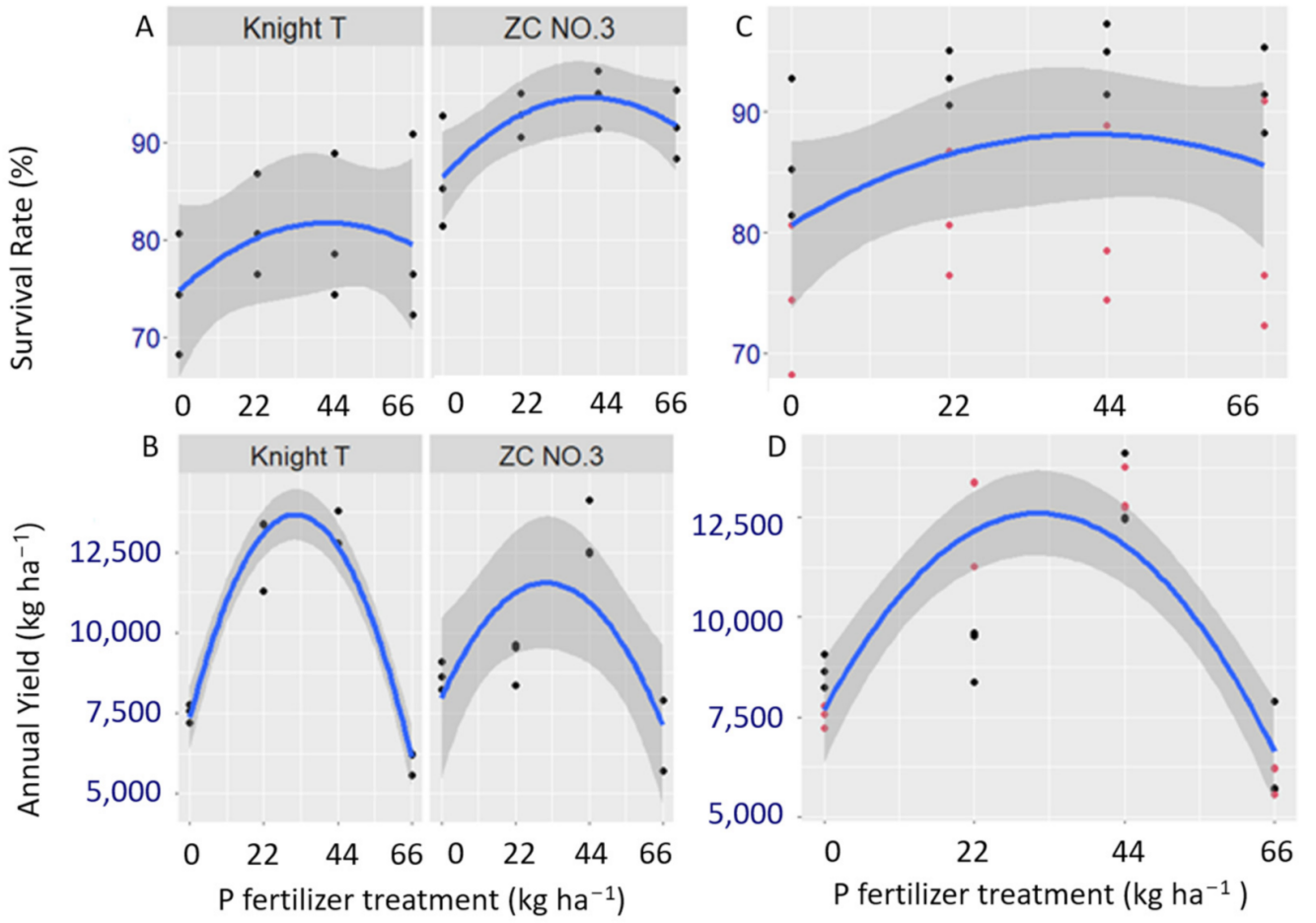

Figure 3. Response curve for winter survival rate and annual forage yield of dormant cultivar ZC NO. 3 and semi-dormant cultivar Knight T in the Agro-pastoral Experiment Station at Shaerqin town, Tumote Banner, Inner Mongolia, China. (A) Percent winter survival of Knight T and ZC NO. 3. (B) Annual forage yield of Knight T and ZC NO. 3. (C) Average percent winter survival for the two cultivars. (D) Average annual forage yield for the two cultivars. Red dots in (C,D) are for cultivar Knight T, and blue dots are for ZC NO. 3; $\mathrm{n}=3$.

Table 9. Dry matter yield $\left(\mathrm{kg} \mathrm{ha}^{-1}\right)$ of dormant cultivar ZC NO. 3 and semi-dormant cultivar Knight $\mathrm{T}$ in the Agro-pastoral Experiment Station at Shaerqin town, Tumote Banner, Inner Mongolia, China.

\begin{tabular}{|c|c|c|c|c|c|c|c|c|}
\hline \multirow{2}{*}{$\begin{array}{l}\text { Treatment } \\
\left(\operatorname{kg} P \text { ha }^{-1}\right)\end{array}$} & \multicolumn{2}{|c|}{ Cut 1} & \multicolumn{2}{|c|}{ Cut 2} & \multicolumn{2}{|c|}{ Cut 3} & \multicolumn{2}{|c|}{ Annual } \\
\hline & ZC NO. 3 & Knight T & ZC NO. 3 & Knight T & ZC NO. 3 & Knight T & ZC NO. 3 & Knight T \\
\hline 0 & $3403.09 \mathrm{Ca}$ & $2183.60 \mathrm{Cb}$ & $2450.98 \mathrm{BCa}$ & $2385.62 \mathrm{Ba}$ & $2803.28 \mathrm{ABa}$ & $2950.82 \mathrm{Ba}$ & $8657.35 \mathrm{Ba}$ & $7520.04 \mathrm{Bb}$ \\
\hline 22 & $4486.88 \mathrm{Ba}$ & $4229.77 \mathrm{Ba}$ & $2712.42 \mathrm{Bb}$ & $4379.08 \mathrm{Aa}$ & 1967.21 Bb & $4065.57 \mathrm{Aa}$ & $9166.51 \mathrm{Bb}$ & $12,674.43 \mathrm{Aa}$ \\
\hline 44 & $5534.32 \mathrm{Aa}$ & $5317.14 \mathrm{Aa}$ & $4117.65 \mathrm{Aa}$ & 3856.21 Aa & $3377.05 \mathrm{Aa}$ & $3934.43 \mathrm{Aa}$ & $13,029.02 \mathrm{Aa}$ & $13,107.78 \mathrm{Aa}$ \\
\hline 66 & $2271.16 \mathrm{Da}$ & $1077.01 \mathrm{Db}$ & $1699.35 \mathrm{Ca}$ & $964.05 \mathrm{Cb}$ & $2459.02 \mathrm{ABa}$ & 3967.21 Aa & $6429.53 \mathrm{Ca}$ & $6008.28 \mathrm{Ca}$ \\
\hline
\end{tabular}

Note: Different capital letters in the same column indicate significant differences among P treatments; different lowercase letters in the same row indicate significant differences between cultivars $(p<0.05) ; \mathrm{n}=3$.

The response curve for annual forage yield to $P$ treatment was more curved than the response curve for survival rate (Figure 3). To pursue higher forage yield, the optimal amount of $\mathrm{P}$ fertilizer for ZC NO. 3 is $31.3 \mathrm{~kg} \mathrm{P} \mathrm{ha}^{-1}$, and that for Knight T is $31.5 \mathrm{~kg} \mathrm{P} \mathrm{ha}^{-1}$, which came from the quadratic regression equations $\mathrm{Y}=7966.582+229.518 \times \mathrm{P}-3.672 \times \mathrm{P}^{2}$ and $\mathrm{Y}=7379.452+399.102 \times \mathrm{P}-6.329 \times \mathrm{P}^{2}$, respectively. The optimal amount of $\mathrm{P}$ fertilizer for maximum annual forage yield was $31.4 \mathrm{~kg} \mathrm{P} \mathrm{ha}^{-1}$, which is less than the fertilizer needed for maximum winter survival rate. $P$ fertilizer for maximum annual forage yield came from the quadratic regression equation $\mathrm{Y}=7673.023+314.31 \times \mathrm{P}-5.001 \times \mathrm{P}^{2}$. 


\section{Discussion}

$\mathrm{P}$ fertilizer is recognized as a key factor in alfalfa biomass yield and winter survival. However, few studies have investigated optimal $P$ fertilizer rates to maximize yield and plant survival under stressful conditions between dormant and semi-dormant cultivars. We investigated the effects of $\mathrm{P}$ application rates when alfalfa was seeded in late summer at a field site in Tumote Banner, Inner Mongolia, China, which has a semi-arid continental climate that does not favor spring and summer seeding.

\subsection{Winter Survival and Yield Components}

Alfalfa forage yield is determined by plant density, plant height, shoots per plant, and shoot mass. Soil nutrition is one of the management factors that is generally thought to improve alfalfa yield [26]. P application is an important management practice to improve forage yield in alfalfa stands due to the high $\mathrm{P}$ requirements of the crop [27]. When soil $\mathrm{P}$ is limiting, plants tend to show a positive growth response to $\mathrm{P}$ addition [28], and applying the appropriate amount of $\mathrm{P}$ is critical for optimal yields. In our study, both cultivars attained the highest forage yield at a $\mathrm{P}$ fertilizer rate of $44 \mathrm{~kg} \mathrm{P} \mathrm{ha}^{-1}$. With higher $\mathrm{P}$ fertilizer rates, the yield of the third cut was still maintained at a high level, especially for the semi-dormant cultivar. As the shortening of the photoperiod in autumn coincides with a fall in temperature, the growth and development of alfalfa changed, in which the dormant cultivar was more sensitive than the semi-dormant cultivar [29].

The winter survival rate and plant density can be used as an index to reflect the overwintering ability and persistence of alfalfa [30]. Previous studies showed that the addition of $P$ fertilizer reduced alfalfa populations [31]. In our study, applying $P$ fertilizer in late-summer of the establishment year did not have a significant effect on plant density, but had a significant effect on winter survival rates in the following year. The winter survival rate was measured earlier in the year, and the population density was measured later. This may be because the plants that survive in spring may die in the later growth process due to frostbite, diseases, and pests.

Plant height has a significant direct effect on forage yield [32]. Increasing plant height is one way to increase alfalfa yield. Plant height can be significantly increased by $\mathrm{P}$ fertilizer in the establishment year [33]. In our study, P fertilizer rates less than $44 \mathrm{~kg} \mathrm{P} \mathrm{ha}^{-1}$ increased plant height of the first two cuts. The plant heights of both cultivars in the first two cuts were not significantly different, but those of the semi-dormant cultivar in the third cut were higher than those of the dormant cultivar. The plant height in the first production year not only depends on weather and soil factors, but is also related to fall dormancy. In the first two cuts, the weather and soil factors contribute more, but in the third cut, the differences in height were mainly due to differences in fall dormancy [34]. Dormant cultivars are sensitive to changes in photoperiod and temperature in autumn, exhibiting slow or stagnant growth, whereas semi-dormant cultivars are less responsive, exhibiting continued erect growth $[35,36]$.

The number of shoots per plant is the yield component that is thought to maintain a high yield, reflecting the individual branching ability and robustness of plants [37]. Under conditions of sufficient nutrients, $\mathrm{P}$ application significantly increased the branch number of alfalfa stems, thus increasing the yield of alfalfa [38]. In our study, the number of shoots per plant in the first cut did not vary with $P$ fertilization. In the second and third cuts, there was an increase in shoot number with suitable $\mathrm{P}$ application. The shoot number response to $\mathrm{P}$ may be more dramatic when plant populations decline to 22 or fewer plants $\mathrm{m}^{-2}$ [39].

Shoot mass is a yield component that is consistently positively associated with forage yield at every harvest, and it was shown to consistently respond to $P$ fertilizer [22]. In our study, we also observed a positive response of shoot mass with the increase in P fertilization, especially for the dormant alfalfa in the first and third cut. The dormant alfalfa starts to regrow late in spring [40] and grows slow in autumn after the last cut [41]. The application of $\mathrm{P}$ fertilizer promoted the growth of dormant alfalfa in spring and autumn and laid the foundation for increasing forage yield. 


\subsection{Root Traits Response to P Fertilizer}

$\mathrm{P}$ is closely related to root development and root morphological traits, and plays a vital role in high forage yield and maintaining agronomic characteristics of cultivars [42]. Application of P fertilizer significantly increased the number of buds in both dormant and semi-dormant cultivars; however, the semi-dormant alfalfa consistently had more crown buds than the dormant alfalfa cultivar. A high number of crown buds should result in more stems in the next spring $[43,44]$. The crown depth increased first and then decreased with increased P fertilizer, but the semi-dormant cultivar showed the strongest response. The alfalfa plants with deep crowns showed greater persistence and more stems than plants with shallow crowns [45]. The crown diameter of the semi-dormant alfalfa increased significantly with the $\mathrm{P}$ fertilization compared to the dormant alfalfa. Crown diameter is genetically determined and a larger crown is related to higher potential yield performance [44]. The taproot diameter and lateral root diameter increased, whereas the depth of the first lateral root and the number of lateral roots decreased, with the increase in $P$ fertilizer. Taproot diameter, depth of the first lateral root, and the number of lateral roots of the semi-dormant alfalfa were more sensitive to $P$ fertilizer than the dormant cultivar. The results showed that moderate application of $\mathrm{P}$ fertilizer promoted root development of alfalfa, especially for semi-dormant alfalfa.

\section{Conclusions}

Applying the correct amount of $P$ fertilizer can increase forage yield and enhance the persistence of late-summer seeded alfalfa by promoting the development of crown and root traits and improving the winter survival rate, especially for semi-dormant cultivars. Latesummer planting and application of $\mathrm{P}$ fertilizer were shown to be a successful practice for establishing alfalfa in arid and cold winter regions, and can be used as an important means to improve soil fertility and stabilize soil from wind erosion for sustainable agriculture. To obtain the highest winter survival rate, the optimal $\mathrm{P}$ fertilization rate for dormant

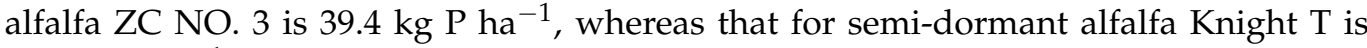
$41.3 \mathrm{~kg} \mathrm{P} \mathrm{ha}^{-1}$. If high yield is pursued, their optimum $\mathrm{P}$ application rates are 31.3 and $31.5 \mathrm{~kg} \mathrm{P} \mathrm{ha}^{-1}$, respectively.

Supplementary Materials: The following supporting information can be downloaded at: https: / /www.mdpi.com/article/10.3390/agronomy12020327/s1, Table S1: Summary of the repeated measures three-way ANOVA analyses of plant height, Table S2: Summary of the repeated measures three-way ANOVA analyses of shoots per plant, Table S3: Summary of the repeated measures three-way ANOVA analyses of shoot mass, Table S4: Summary of the repeated measures three-way ANOVA analyses of forage yield.

Author Contributions: Y.W. and L.Y. designed the study and revised the manuscript. Y.W. carried out the research and wrote the manuscript. J.Z. provided assistance in data acquisition. Z.X. coanalyzed some of the data, and D.A.S. revised the manuscript. All authors have read and agreed to the published version of the manuscript.

Funding: This research was financially supported by Inner Mongolia Science and Technology Department 2019GG260 and 2019CG041. The funding body had no contribution to the study's design, the data collection, analysis, interpretation, or writing of the manuscript.

Data Availability Statement: The data presented in this study are available on request to the corresponding author.

Conflicts of Interest: The authors declare no conflict of interest.

\section{References}

1. Mao, X.; Li, Q.; Ren, L.; Bai, W.; Zhang, W. Application of molybdenum fertilizer enhanced quality and production of alfalfa in northern China under non-irrigated conditions. J. Plant Nutr. 2018, 41, 1009-1019. [CrossRef]

2. Fernandez, A.; Sheaffer, C.; Tautges, N.; Putnam, D.; Hunter, M. Alfalfa, Wildlife and the Environment; National Alfalfa and Forage Alliance: Saint Paul, MN, USA, 2019. 
3. Thinguldstad, B.; Tucker, J.J.; Baxter, L.L.; Segers, J.R.; Hancock, D.W.; Stewart, R.L. Alfalfa response to low potassium under different harvest regimes in Coastal Plains. Agrosystems Geosci. Environ. 2020, 3, e20029. [CrossRef]

4. Yost, M.A.; Morris, T.F.; Russelle, M.P.; Coulter, J.A. Second-year corn after alfalfa often requires no fertilizer nitrogen. Agron. J. 2014, 106, 659-669. [CrossRef]

5. Xue, S.D. The effects and position of natural grassland on controlling soil erosion and desertification in watershed of the middle and upper reaches of Yellow River. Acta Agrestia Sin. 2000, 8, 77-81.

6. Yang, J.; Tian, F.; Zhao, X. Study on benefits of alfalfa conservating soil and water. J. Soil Eros. Soil Water Conserv. 1997, 2, 91-96.

7. Liu, M.; Zheng, Y. An experiment and demonstration on alfalfa base establishment in dongshawo area of Wuwei region. J. Gansu Agric. Univ. 2001, 292-296. [CrossRef]

8. Johnson, L.D.; Marquez-Ortiz, J.J.; Lamb, J.F.S.; Barnes, D.K. Root morphology of alfalfa plant introductions and cultivars. Crop Sci. 1998, 38, 497-502. [CrossRef]

9. Kuijt, J.; Hansen, B. Morphology and Anatomy. In Flowering Plants. Eudicots; Springer International Publishing: Berlin, Germany, 2005; Volume 12, pp. 7-15.

10. MarquezOrtiz, J.J.; Johnson, L.D.; Barnes, D.K.; Basigalup, D.H. Crown morphology relationships among alfalfa plant introductions and cultivars. Crop Sci. 1996, 36, 766-770. [CrossRef]

11. Johnson, L.D.; Marquez-Oritiz, D.K.; Barnes, D.K.; Lamb, J.F.S. Inheritance of root Traits in alfalfa. Crop Sci. 1996, 36, 1482-1487. [CrossRef]

12. Yang, Y.; Ran, S.; Li, J.; Xue, Y. Effects of exponential fertilization on growth and root morphology of Tilia amurensis seedlings. J. Nanjing For. Univ. 2020, 44, 91-97. [CrossRef]

13. Zhao, Y.J.; Liu, X.J.; Tong, C.C.; Wu, Y. Effect of root interaction on nodulation and nitrogen fixation ability of alfalfa in the simulated alfalfa/triticale intercropping in pots. Sci. Rep.-UK 2020, 10, 4269. [CrossRef] [PubMed]

14. Fan, Q.; Creamer, R.; Li, Y. Time-course metabolic profiling in alfalfa leaves under Phoma medicaginis infection. PLoS ONE 2018, 13, e0206641. [CrossRef] [PubMed]

15. Su, Y.Z. Soil carbon and nitrogen sequestration following the conversion of cropland to alfalfa forage land in northwest China Soil Tillage Res. 2007, 92, 181-189. [CrossRef]

16. Zhang, H. Research on the Sustainable Development of Pasture Animal Husbandry in Inner Mongolia; Northwest Agricultural and Forest University: Shaanxi, China, 2019.

17. Davis, A.S.; Hill, J.D.; Chase, C.A.; Johanns, A.M.; Liebman, M. Increasing cropping system diversity balances productivity, profitability and environmental health. PLOS ONE 2012, 7. [CrossRef]

18. Xia, Y.H.; Wulantuya; Qiang, H. Research progress of definition of farming-pastoral zone in northern China. J. Inn. Mong. For. Sci. Technol. 2014, 40, 134-139.

19. Andrzejewska, J.; Albrecht, K.A.; Ignaczak, S.; Skinder, Z. Method and time of alfalfa sowing when climate is changing. Acta Sci. Pol. Agric. 2015, 14, 3-13.

20. Pokoo, R.; Ren, S.; Wang, Q.; Motes, C.M.; Hernandez, T.D.; Ahmadi, S.; Monteros, M.J.; Zheng, Y.; Sunkar, R. Genotype-and tissue-specific mirna profiles and their targets in three alfalfa (Medicago sativa L.) genotypes. BMC Genom. 2019, 19, 913. [CrossRef]

21. Malhi, S.S.; Arshad, M.A.; Gill, K.S.; McBeath, D.K. Response of alfalfa hay yield to phosphorus fertilization in two soils in central alberta. Commun. Soil Sci. Plant Anal. 2008, 23, 717-724. [CrossRef]

22. Berg, W.K.; Cunningham, S.M.; Brouder, S.M.; Joern, B.C.; Johnson, K.D.; Santini, J.B.; Volenec, J.J. The long-term impact of phosphorus and potassium fertilization on alfalfa yield and yield components. Crop Sci. 2007, 47, 2198-2209. [CrossRef]

23. Griffiths, B.S.; Spilles, A.; Bonkowski, M. C:N:P stoichiometry and nutrient limitation of the soil microbial biomass in a grazed grassland site under experimental P limitation or excess. Ecol. Processes 2012, 1, 6. [CrossRef]

24. Ventroni, L.M.; Volenec, J.J.; Cangiano, C.A. Fall dormancy and cutting frequency impact on alfalfa yield and yield components. Field Crops Res. 2010, 119, 252-259. [CrossRef]

25. Kassambara, A. Pipe-Friendly Framework for Basic Statistical Tests [R Package Rstatix Version 0.7. 0]; R Foundation for Statistical Computing: Vienna, Austria, February 2021. Available online: https://mran.microsoft.com/web/packages/rstatix/index.html; https:/ / www.r-project.org/ (accessed on 15 December 2021).

26. Wang, Q.; Sun, D.; Hou, X. Optimization of irrigation frequency and application norm of phosphorus fertilizer for alfalfa in semiarid region of northern Shanxi province. Trans. Chin. Soc. Agric. Eng. 2012, 28, 112-117. [CrossRef]

27. Bi, Y.X.; Zhou, P.; Li, S.J.; Wei, Y.Q.; Xiong, X.; Shi, Y.H.; Liu, N.; Zhang, Y.J. Interspecific interactions contribute to higher forage yield and are affected by phosphorus application in a fully-mixed perennial legume and grass intercropping system. Field Crops Res. 2019, 244, 107636. [CrossRef]

28. Moreira, A.; Fageria, N.K.; Garcia, A.G.Y. Effect of liming on the nutritional conditions and yield of alfalfa grown in tropical conditions. J. Plant Nutr. 2011, 34, 1904. [CrossRef]

29. Brouwer, D.J.; Duke, S.H.; Osborn, T.C. Mapping genetic factors associated with winter hardiness, fail growth, and freezing injury in autotetraploid alfalfa. Crop Sci. 2000, 40, 1387-1396. [CrossRef]

30. Hendrickson, J.R.; Berdahl, J.D. Survival of 16 alfalfa populations space planted into a grassland. J. Range Manag. 2003, 56, 260-265. [CrossRef]

31. Sanderson, M.A.; Jones, R.M. Stand dynamics and yield components of alfalfa as affected by phosphorus fertility. Agron. J. 1993, 85, 241-246. [CrossRef] 
32. Xie, K.Y.; Li, X.L.; He, F.; Zhang, Y.J.; Wan, L.Q.; Hannaway, D.B.; Wang, D.; Qin, Y.; Fadull, G.M.A. Effect of nitrogen fertilization on yield, $\mathrm{N}$ content, and nitrogen fixation of alfalfa and smooth bromegrass grown alone or in mixture in greenhouse pots. $J$. Integr. Agric. 2015, 14, 1864-1876. [CrossRef]

33. Li, X.; Hou, X.; Mu, H.; Li, X.; Guo, F. P fertilization effects on the accumulation, transformation and availability of soil phosphorus. Acta Prataculturae Sin. 2015, 24, 218-224.

34. Borowiecki, J.; Gawel, E.; Guy, P. Wzrost i plonowanie oraz jakosc masy roslinnej krajowych i zagranicznych odmian lucerny. I Tempo wzrostu i plonowanie. Pamiętnik Puławski 1997, 111, 35-50.

35. Liu, Z. Evaluation of Fall Dormancy Rating among Different Alfalfa (Medicago Sativa L.) Cultivars and Effect Mechanisms of Fall Dormancy on Winter Survival Rate; China Academic of Agricultural Sciences: Beijing, China, 2016.

36. Bertrand, A.; Castonguay, Y. Plant adaptations to overwintering stresses and implications of climate change. Rev. Can. De Bot. 2004, 81, 1145-1152. [CrossRef]

37. Li, C.P.; Qiu, Y.H.; Xia, H.Y.; Tan, L.N.; Xu, H.Y.; Zhang, H.W.; Gao, J.H. Membership function analysis of low transpiration and yield traits in alfalfa multi-paternal hybrid f1 generation. Acta Agrestia Sinca 2021, 29, 1416-1422. [CrossRef]

38. Jiang, H.; Shen, Y.; Zhai, G.; Liu, Z. Effect of phosphate fertilizer on the shoot growth and forage yield of Medicago Sativa L. Acta Agrestia Sinca 2009, 17, 588-592.

39. Volenec, J.J.; Cherney, J.H.; Johnson, K.D. Yield components, plant morphology, and forage quality of alfalfa as influenced by plant population. Crop Sci. 1987, 27, 321-326. [CrossRef]

40. Wang, X.L.; Mi, F.G.; Li, H.; Jin, H.Q.; Xiao, Y.Z.; Yang, W.G.; Yang, Z.; Wang, Q.Z. Comparison of yield, nutrition and winter surviving rate of alfalfa varieties with different fall dormancy levels. J. Northwest A F Univ. (Nat. Sci. ED) 2019, 47, 7-13+22. [CrossRef]

41. Li, X.L.; Wan, L.Q. Alfalfa fall dormancy and its relationship to winter hardiness and yield. Acta Prataculturae Sin. 2004, 13, 57-61.

42. Hao, F.; Liu, X.J.; Qi, M.X.; Zhang, X.L. Effects of phosphate levels and rhizobium inoculation on the root morphology and nitrogen fixing characteristic of alfalfa. Acta Agrestia Sinca 2015, 23, 818-822. [CrossRef]

43. Mairquez-Ortiz, J.J.; Lamb, J.F.S.; Johnson, L.D.; Barnes, D.K.; Stucker, R.E. Heritability of crown traits in alfalfa. Crop Sci. 1999, 39, 38-43. [CrossRef]

44. Brummer, E.C.; Bouton, J.H. Plant traits associated with grazing-tolerant alfalfa. Agron. J. 1991, 83, 996-1000. [CrossRef]

45. Peng, L.; Li, X.; Qi, X.; Li, S.; Yue, Y.; Wang, Y. The relationship of root traits with persistence and biomass in 10 alfalfa varieties. Acta Prataculturae Sin. 2014, 23, 147-153. [CrossRef] 